\title{
ARTEFAK PERUNGGU PRASEJARAH SITUS PASIR ANGIN BOGOR: HUBUNGANNYA DENGAN ASPEK SUMBER BAHAN
}

\section{PREHISTORIC BRONZE ARTIFACTS \\ FROM PASIR ANGIN SITE, BOGOR: ITS CORRELATION TO THEIR MATERIAL SOURCES}

\author{
Sudarti Prijono \\ Balai Arkeologi Jawa Barat \\ Sudarti25@yahoo.com
}

\begin{abstract}
Pasir Angin site is located in the western part of Java Island kept many artifacts coming from metal materials bronze. Bronze at the site was found in context as a means or equipment worship ancestral spirits. The context also shows that Bronze at the time it was considered a luxury item, and community allegedly Pasir Angin was first exposed to goods of metal materials that are the result of high technology. On this site can not be found the remains of bronze production, so it alleged that no local production of bronze artifacts, but to come from surplus areas such objects and how spreading. Through metallographic analysis showed that bronze objects Pasir Angin site making techniques have similarities with the Dong Son bronze objects. In addition, there were traces of shipping and commercial activities that have ever taken place between the Chinese in this case with Indonesia Dong Son bronze objects strengthens the case originated from the region. Thus the site became Pasir Angin setrategis region that gave birth to early civilizations utilization of high technology. The findings of bronze objects on this site strengthens the case that Java has entered International network since the perundagian.
\end{abstract}

Keywords: Bronze, Row Materials, Distribution

\begin{abstract}
ABSTRAK
Situs Pasir Angin yang terletak di Pulau Jawa bagian barat banyak menyimpan artefak berasal dari bahan logam perunggu.Perunggu di situs ini ditemukan dalam konteknya sebagai sarana atau perlengkapan pemujaan arwah leluhur.Konteks tersebut juga menunjukkan bahwa Perunggu pada pada masa itu dianggap sebagai barang mewah, dan diduga komunitas Pasir Angin pertama kalinya mengenal barang dari bahan logam yang merupakan hasil teknologi tinggi.Di situs ini tidak ditemukan sisa-sisa produksi perunggu, sehingga muncul dugaan bahwa artefak perunggu bukan produksi lokal melainkan di datangkan dari wilayah yang surplus benda tersebut dan bagaimana persebarannya.Melalui analisis metalografi dapat diketahui bahwa benda perunggu situs Pasir Angin mempunyai persamaan teknik pembuatan dengan benda perunggu Dong Son.Di samping itu adanya jejak-jejak pelayaran dan aktivitas perniagaan yang pernah berlangsung antara Cina dalam hal ini Dong Son dengan Indonesia memperkuat dugaan benda perunggu berasal dari wilayah tersebut.Dengan demikian situs Pasir Angin menjadi wilayah setrategis yang melahirkan peradaban awal pemanfaatan teknologi tinggi. Temuan benda perunggu di situs ini memperkuat dugaan bahwa wilayah Jawa telah masuk jaringan Internasional sejak masa perundagian.
\end{abstract}

Kata Kunci: Perunggu, Sumber Bahan, Persebaran

Tanggal masuk : 27 Februari 2016

Tanggal diterima : 31 Mei 2016 


\section{PENDAHULUAN}

Soegondo dan Aziz (1988: 305-324) dalam Rapat Evaluasi Hasil Penelitian Arkeologi III menyatakan bahwa hasil ekskavasi di Situs Prasejarah Pasir angin, Kabupaten Bogor yang dilaksanakan oleh Pusat Penelitian Arkeologi Nasional dan Ditlinbinjarah pada tahun 1971-1975 menemukan data arkeologi berupa artefak hasil teknologi logam perunggu. Adapun artefak perunggu yang dimaksud di antaranya kapak, candrasa, boneka, hiasan, bandul kalung (liontin), mangkuk serta temuan sisa logam lain berupa terak besi. Keragaman bentuk artefak tersebut, merupakan sebagian hasil teknologi yang dianggap sebagai mekanisme kultural manusia dalam upaya penyesuaian diri terhadap lingkungan alam. Dengan demikian, maka keragaman bentuk artefak juga merupakan hasil budaya akibat adanya penyesuaian terhadap lingkungan alam. Hal ini sesuai dengan sebutan yang diberikan para ahli kepada komunitas Pasir Angin masa lalu sebagai kelompok manusia yang telah memiliki tingkat budaya yang tinggi. Kelompok masyarakat ini telah memiliki keahlian untuk mengubah, menyebarkan, dan menggunakan sumberdaya alam khususnya bijih logam besi menjadi sarana hidup sehari-hari, di samping alat-alat dari logam perunggu.Dalam kaitannya dengan tulisan ini logam perunggu digunakan sebagai pokok bahasan.

Sementara

itu,

perkembangan teknologi logam khususnya perunggu di Indonesia tidak terlepas dari budaya perunggu di Asia Daratan. Di Vietnam budaya perunggu telah berkembang sekitar awal tahun 2000 SM, yaitu pada periode Go Bang atau Phung
Nguyen akhir, yang mana periode ini merupakan transisi dari Neolitik ke Jaman Perunggu (Kempers 1988:268). Jaman tersebut kemudian berlanjut pada jaman Perunggu tengah $(1120 \pm 100 \mathrm{SM})$, yaitu periode Dong Dau. Pada jaman ini alat-alat batu mulai digantikan dengan alat-alat berbahan campuran tembaga dan timah dengan perbandingan $80 \%$ Cudan $20 \%$ Sn. Adapun jaman perunggu akhir di Vietnam pada pertanggalan radiokarbon $1095 \pm 120 \mathrm{SM}$, yaitu tatkala jaman kebudayaan Go Mun. Periode ini juga disebutkan sebagai perkembangan tingkat lanjut dari tradisi pertukangan logam. Tradisi ini ditandai oleh berbagai jenis peralatan perunggu berupa mata pancing, mata lembing, mata panah, kalung, sabit, bejana, nekara, kapak, dan gelang (Soejono, 1992: 243). Perunggu Dong Son mulai muncul saat ini atau disebut pula sebagai jaman permulaan munculnya pertukangan besi, namun perunggu masih digunakan pada jaman-jaman berikutnya. Benda-benda perunggu khususnya nekara yang ditemukan di Indonesia menunjukkan persamaan dengan temuan-temuan di Dong Son baik bentuk maupun pola hiasnya. Persebaran nekara perunggu secara geografis di Indonesia sangat luas antara lain di Sumatra, Jawa, Bali, dan Indonesia Timur (Bintarti, 1987: 20-30).

Periode awal logam di Indonesia disebut sebagai masa perundagian. Dalam masa ini teknologi berkembang pesat dimulai dengan penemuan-penemuan baru berupa teknik peleburan, pencampuran, penempaan, pencetakan jenis-jenis logam. Namun sebelumnya juga sudah dikenal adanya logam tembaga dan emas (Soejono, 1992: 218-226). Kedua jenis logam ini sangat mudah 
dilebur. Titik lebur emas murni 1063 ${ }^{\circ} \mathrm{C}$ dan titik lebur tembaga $1083{ }^{\circ} \mathrm{C}$ keduanya merupakan logam lunak dengan kekerasan sekitar 2,5-3 skala mohs dan elastisitas dari kedua logam tersebut sekitar 27 $\mathrm{kg} / \mathrm{cm} 2$ sehingga mudah dibentuk. Sifat lunak logam ini tidak mendukung untuk digunakan sebagai senjata atau perkakas logam yang bersifat keras. Perkembangan selanjutnya baru beberapa ribu tahun kemudian setelah ditemukan teknik pembakaran, dan penuangan logam. Sekitar tahun 4000 SM pengrajin logam di Timur Tengah dan Asia Tenggara berhasil memperbaiki sifat tembaga dengan mencampurkan unsur logam kedua yaitu arsenikum atau timah menjadi perunggu (Hodges, 1968: 69).

Kemahiran teknik atau undagi logam di Indonesia berlangsung beberapa abad sebelum Masehi dan dibuktikan melalui penemuan benda-benda perunggu dan benda logam lainnya yang oleh Van Heekeren (1958: 1220) dikenal dengan "Masa Perunggu dan Besi" (Bronze-Iron Age).

Sejarah perkembangan logam menyebutkan bahwa perunggu merupakan logam campuran tertua yang telah digunakan manusia (Hodges, 1968:70-76). Campuran logam tembaga dan timah ini ternyata menghasilkan benda-benda yang lebih keras dan kuat. Surdia dan Chiijiwa (1986: 40-43) menyatakan bahwa perunggu adalah paduan logam tembaga timah, dan biasanya kandungan timah kurang dari $15 \%$. Perunggu dengan timah kurang dari $5 \%$ berwarna kekuningan, sedangkan kadar timah di atas $15 \%$ menjadi warna kuning-merah.

Salah satu situs prasejarah di Indonesia yang menghasilkan arterfak logam kususnya perunggu adalah situs Pasir Angin. Terdapat beberapa penyebutan mengenai situs ini di antaranya berdasarkan pertanggalan radiokarbon yang dihasilkan situs berasal dari periode $4370 \pm 1190 \mathrm{BP}$ dan termuda $1050 \pm$ 160 BP (Soegondo dan Aziz, 1988: 311). Selanjutnya R.P Soejono (1992) meletakkan Situs Pasir Angin dalam periode Prasejarah Indonesia sebagai situs masa perundagian. Situs ini telah digunakan oleh komunitas masa perundagian dengan pola hidup menetap (sedenter) dan menggunakan teknologi logam yang lebih maju untuk memenuhi kebutuhan hidup.

Kemudian berdasarkan hasil penelitian terhadap data artefak berupa manik-manik, tempayan dan periuk dengan pola hias jala, tali, serta duri ikan yang berada pada satu kontek dengan artefak perunggu berupa kapak seriti tipe Soejono IIA dan IIB, candrasa, tongkat disimpulkan bahwa artefakartefak tersebut merupakan sarana upacara (Anggraeni dan Due Awe, 1988: 343). Selanjutnya mengacu pada monolit yang ada dipuncak bukit dan data artefak dari dalam tanah, yang konteks keletakan membujur atau menghadap ketimur arah bidang datar utama monolit, maka situs Pasir Angin dikelompokan sebagai tempat pemujaan atau tempat upacara pengagungan arwah leluhur

( Sukendar, 1988: 368).

Teknologi logam masa perundagian di Situs Pasir Angin merupakan suatu peningkatan ilmu pengetahuan manusia tentang pemanfaatan teknologi. Hal ini diketahui dari hasil penelitian yangmenunjukkan bahwa situs ini memiliki artefak hasil teknologi yang beragam dari jenis logam perunggu, 
besi, alat batu, keramik, gerabah, dan logam lainnya (emas).

Komunitas pendukung situs

Pasir Angin menggunakan perkakas logam perunggu, dan besi namun tampaknya hanya artefak berbahan besi yang diproduksi di situs ini. Hal ini dibuktikan dengan adanya temuan terak besi. Sedangkan artefak perunggu yang ditemukan diduga bukan produksi lokal. Pada kondisi demikian masyarakat akan mendatangkan artefak perunggu dari daerah yang surplus komoditi tersebut.

Untuk mengetahui sumber komoditi artefak perunggu dapat dilakukan dengan mempelajari teknologi pembuatan yang masih tersimpan di dalam artefak. Dalam hal ini analisis metalografi dan komposisi unsur logam dapat menjelaskan mengenai proses produksinya (Hodges,1968: 206218; Prijono, 2006:41).

\section{ANALISIS METALOGRAFI DAN KOMPOSISI UNSUR PERUNGGU}

\section{a. Analisis Metalografi}

Dalam sejarah metalurgi, perunggu merupakan logam campuran tertua yang pernah digunakan oleh manusia. Gambaran secara menyeluruh dari teknologi dan komposisi logam perunggu situs Pasir Angin diperoleh dari hasil pengujian metalografi.

Analisis metalografi menurut Thomsons dalam "Science in Archaeology", seperti dikutip oleh Prijono (2006: 39-54) menjelaskan bahwa, mikroskop dapat digunakan untuk mempelajari struktur logam purba, dan secara bersamaan dalam mikrostruktur yang sama juga memperlihatkan perlakuan baik pendinginan maupun penempaan benda logam. Metode ini telah dipraktekkan oleh Smith (1973: 21-
32) terhadap perunggu dari Situs Non Nok Tha dan Situs Ban Chiang di Thailand. Melalui analisis tersebut jejak-jejak kegiatan proses pembuatan artefak logam dapat diketahui. Jejak-jejak tersebut tersimpan di dalam mikrostruktur dari artefak logam yang dianalisis, di antaranya berupa jejak proses pemanasan dan perlakuan teknik lainnya seperti penuangan, penempaan, pelunakan (penganilan), penggilasan, dan gabungan dari perlakuan-perlakuan tersebut yang telah digunakan oleh manusia (Fagan, 1991: 301-308; Prijono, 2006: 41).

\section{Analisis Gambar. 1}

Berasal dari sampel tangkai kapak perunggu tipe Soejono IIA (seriti) merupakan hasil ekskavasi tahun 1972 di sektor LPXXII, kotak J5-H5, diperoleh gambar mikrostruktur yang diperbesar 350 kali, dan etsa menggunakan campuran $\quad \mathrm{H}_{2} \mathrm{O}_{2} \quad$ (hydrogen peroksida), $\quad \mathrm{NH}_{4} \mathrm{OH}$ (ammonium hidroksida), $\mathrm{FeCl}_{3}$ (ferry clorida). Tampak pertumbuhan dendritis hasil proses penuangan pada suatu cetakan. Bundaran bulat berwarna

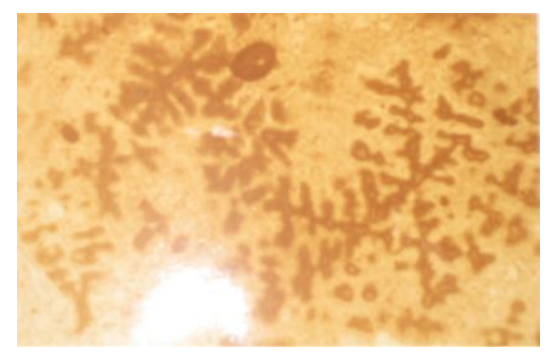

Gambar 1. Hasil analisis metalografi kapak perunggu tipe Soejono IIA (seriti) situsPasir Angin dengan bentuk dendritis fase- $\alpha$. Sumber: dikutip dari Sudarti dalam Forum Arkeologi No. 11. Th. 2006 Balai Arkeologi Denpasar

coklat tua adalah molekul $\mathrm{Pb}$ (timbal) yang terdapat dalam campuran perunggu. 
Analisis Gambar. 2

Berasal dari sampel Nekara perunggu tipe Heger I yang diketahui merupakan hasil kebudayaan Dongson (Vietnam) dan ditemukan di Kabupaten Kuningan, Jawa Barat diperoleh gambar mikrostruktur yang diperbesar 350 kali dari hasil analisis metalografi, dan etsa menggunakan $\mathrm{H}_{2} \mathrm{O}_{2}$ (hydrogen peroksida), $\mathrm{NH}_{4} \mathrm{OH}$ (ammonium hidroksida), $\mathrm{FeCl}_{3}$ (ferry clorida). Tampak hasil proses pemadatan menghasilkan dendritis larutan fase- $\alpha$ (warna coklat) berukuran kecil, dan beberapa fase$\delta$ coklat keputihan) terisolasi. Partikel bulat dan bersudut berwarna coklat tua berasal dari $\mathrm{Pb}$ (timbal). Mikrostruktur yang sama juga ditemukan pada hasil analisis metalografi sampel perunggu Heger IV dari Waleri dan tongkat perunggu dari situs Pasir Angin.

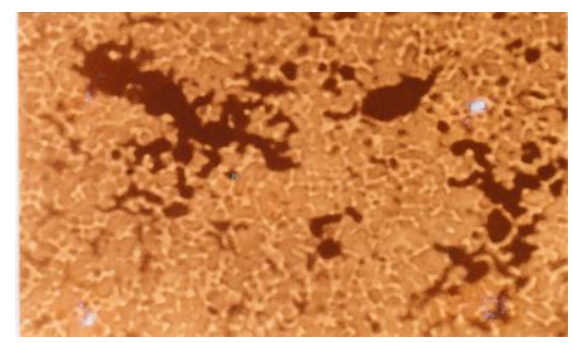

Gambar 2. Hasil analisis metalografi artefak perunggu dari nekara tipe Heger I (Kuningan) dengan bentuk dendritis fase- $\delta$, terbentuk sebagai akibat adanya segregasi/pemisahan pada saat pembekuan, umumnya ditemukan pada bentuk perhiasan dan benda cetakan Sumber: dikutip dari Sudarti dalam tesis S2 Arkeologi FIB, UI. Th. 1999. Hal: 119.

\section{b. Analisis Komposisi Unsur}

Penentuan komposisi unsur perunggu dilakukan dengan analisis kimiawi melalui metode spektrofotometri serapan atom (Atomic Absosrption Spectrophotometries) disingkat AAS (Bassett dkk (1979: 810-813; Aziz dan Sudarti, 1998 :
154-169). Metode ini dilaksanakan berdasarkan kepada prinsip-prinsip dasar absorbsi atau penyerapan cahaya oleh atom-atom dari senyawa unsur logam yang diperiksa.

Atom-atom bebas ini dihasilkan dari suatu senyawa atau unsur-unsur logam yang terurai ketika diberi energi (panas) akan terserap. Cahaya yang diserap oleh atom bebas dari unsur logam ini berhubungan erat dengan tenaga yang dibutuhkan oleh suatu atom untuk mencapai tingkat tenaga tertentu (Eo), dan pada panjang gelombang tertentu $(\lambda)$. Selanjutnya dengan menggunakan prinsipprinsip hukum Lambert dan Beer, yaitu apabila suatu cahaya monokromatis dilewatkan melalui suatu media yang transparan atau tembus pandang, maka menurunya intensitas cahaya yang dipancarkan sebanding dengan bertambah tebalnya dan kepekatan dari media yang digunakan, serta dirumuskan menjadi sebagai berikut:
Absorbansi $(A)=K L C$
$\mathrm{K}$ : koefisien tetap
$\mathrm{L}$ : panjang media
C: konsentrasi (banyaknya) atom dari unsur logam atau senyawa yang ditentukan.

Dalam prakteknya, besaran $\mathrm{K}$ dan $\mathrm{L}$ selalu tetap, sehingga cara termudah dalam penggunaan metode ini adalah dengan jalan mengukur absorbansi larutan standar yang diketahui jumlah kepekatan (persentase) unsurnya, sehingga menghasilkan kurva standard. Selanjutnya absorbansi sampel yang belum diketahui komposisinya dibandingkan dengan absorbansi standard. Pelaksanaan analisis ini dilakukan di Laboratorium Kimia Mineral, Pusat Penelitian Pengembangan Teknologi Mineral, Departemen Pertambangan dan 
Energi, memperoleh data komposisi unsur perunggu masa perundagian dari artefak tongkat dan kapak tipe Soejono IIA dari Pasir Angin, nekara Heger I dari Kuningan dan Heger IV dari Waleri seperti tabel berikut ini. (insol) dan $\mathrm{CuO}$ (tembaga oksida) = $47,48 \%$. Dilihat dari tingginya kandungan timah putih dapat dikategorikan perunggu ini sangat keras diduga digunakan sebagai sarana yang bersifat profan atau

Tabel 1. Komposisi Artefak Perunggu Situs Pasir Angin

\begin{tabular}{|l|l|r|c|c|c|c|c|}
\hline $\begin{array}{l}\mathrm{N} \\
\mathrm{o}\end{array}$ & Nama Unsur & Tongkat & $\begin{array}{c}\text { Kapak } \\
\text { Tipe IIA }\end{array}$ & $\begin{array}{c}\text { Lempen } \\
\mathrm{g}\end{array}$ & $\begin{array}{c}\text { Heger-I } \\
\text { Bogor }\end{array}$ & $\begin{array}{c}\text { Heger-1 } \\
\text { Kuningan }\end{array}$ & $\begin{array}{c}\text { Heger-IV } \\
\text { Waleri }\end{array}$ \\
\hline 1 & $\mathrm{Cu}$ (tembaga) & $19,31 \%$ & $35,70 \%$ & $45,70 \%$ & $87,20 \%$ & $67,15 \%$ & $76,14 \%$ \\
\hline 2 & $\mathrm{Sn}$ (timah) & $7,49 \%$ & $15,21 \%$ & $13,42 \%$ & $3,76 \%$ & $12,65 \%$ & $13,36 \%$ \\
\hline 3 & $\mathrm{~Pb}$ (timbal) & $42,19 \%$ & $1,26 \%$ & $21,33 \%$ & $8,53 \%$ & $12,50 \%$ & $9,91 \%$ \\
\hline 4 & $\mathrm{Zn}$ (seng) & $0,07 \%$ & $0,216 \%$ & $0,07 \%$ & $0,01 \%$ & $0,02 \%$ & $0,06 \%$ \\
\hline 5 & $\mathrm{Fe}$ (besi) & $0,63 \%$ & $0,20 \%$ & $0,34 \%$ & $0,17 \%$ & $2,01 \%$ & $0,23 \%$ \\
\hline 6 & $\mathrm{Co}$ (cobalt) & $\mathrm{Tt}$ & $\mathrm{tt}$ & $0,16 \%$ & $\mathrm{tt}$ & $\mathrm{Tt}$ & $\mathrm{tt}$ \\
\hline 7 & $\mathrm{Bi}$ (bismut) & $\mathrm{Tt}$ & $0,042 \%$ & $0,15 \%$ & $\mathrm{tt}$ & $\mathrm{Tt}$ & $\mathrm{tt}$ \\
\hline 8 & $\mathrm{Ni}$ (nikel) & $\mathrm{tt}$ & $\mathrm{tt}$ & $\mathrm{tt}$ & $0,13 \%$ & $0,01 \%$ & $0,01 \%$ \\
\hline 9 & $\mathrm{SiO}_{2}$ insol & $30,31 \%$ & $47,37 \%$ & $12,94 \%$ & $0,20 \%$ & $5,66 \%$ & $0,29 \%$ \\
\hline & Jumlah & $100,00 \%$ & $99,998 \%$ & & $100 \%$ & $100 \%$ & $100 \%$ \\
\hline
\end{tabular}

Sumber: dikutip dari Sudarti, 1999

Berdasarkan hasil analisis metalografi diperoleh simpulan bahwa pada dasarnya teknologi pembuatan artefak perunggu situs Pasir Angin dilakukan dengan teknik penuangan pada cetakan. Adapun untuk artefak berupa kapak dilanjutkan dengan teknik penempaan. Untuk artefak nekara perunggu Dongson dihasilkan melalui teknik penuangan pada cetakan tanpa dilanjutkan dengan teknik penempaan. Adapun jika ditinjau dari komposisi unsurnya perunggu nekara Dongson mempunyai tiga unsur logam penyusun utama, yaitu $\mathrm{Cu}$ (tembaga), Sn (timah), dan $\mathrm{Pb}$ (timbal),demikian pula perunggu situs Pasir Angin juga tersusun dari tiga unsur utama, tembaga, timah, timbal kecuali kapak IIA yang hanya tersusun dari dua unsur utama. Besaran komposisi unsur perunggu Pasir Angin mengandung unsur insol $\mathrm{SiO}_{2}$ insol yang sangat besar, misalnya pada artefak kapak IIA dengan komposisi, campuran $\mathrm{SiO}_{2}$ untuk memenuhi kebutuhan hidup sehari-hari, namun jika dilihat dari kandungan $\mathrm{SiO}_{2}$ (insol) dan $\mathrm{CuO}$ yang tinggi memberikan gambaran bahwa perkakas perunggu ini sudah mengalami perusakan lanjut.

Berlatar pada temuan tersebut diperoleh gambaran bahwa artefak dibuat dengan cara yang sederhana dengan cetakan yang terbuat dari campuran tanah liat dan pasir, serta artefak terkubur di dalam tanah dengan tingkat keasaman yang tinggi. Namun dapat pula berasal dari bahan baku yang digunakan bukan berasal dari campuran tembaga, timah, dan timbal siap pakai, melainkan berasal dari batuan mineral alam yang dicampur dan dilelehkan, atau berasal dari bahan daur ulang untuk dijadikan barang baru (Sudarti, 1998).Terkait dengan hasil analisis tersebut permasalahan yang muncul adalah mengenai keberadaan artefak perunggu di situs Pasir Angin. Sementara sisa-sisa produksi logam tersebut tidak ditemukan, dan 
cadangan tembaga di Jawa baru ditemukan setelah PT Aneka Tambang pada tahun 1974 meneliti deposit tembaga dengan kadar 0,34 $\% \mathrm{Cu}$ (tembaga), 1,99 \% Pb (timbal), dan 4,05\% Zn (seng)yang terletak di Gunung Limbung, Kabupaten Sukabumi (Supiyem, 1985: 30). Berdasarkan data tersebut maka dapat dikatakan bahwa artefak perunggu didatangkan dari daerah yang surplus komoditi tersebut atau sebagai komoditi yang diperdagangkan, serta dari mana berasal.

Hal tersebut dapat dibuktikan melalui beberapa sumber. Diketahui bahwa sebaran nekara perunggu tipe Heger I di Indonesia sangat luas mulai dari Sumatra hingga Indonesia Bagian Timur. Nekara perunggu yang ditemukan di Jawa umumnya nekara tipe Heger I, kecuali dua buah yang ditemukan di Banten dan Waleri tipe Heger IV. Hal ini menimbulkan dugaan tentang adanya hubungan budaya yang berkembang di Dong Son dengan di Indonesia (Soejono, 1992: 234).

\section{KERANGKA PEMIKIRAN}

Dalam ilmu ekonomi dikenal dua kegiatan, yaitu ekonomi subsistensi dan ekonomi pasar. Ekonomi subsisten ialah ekonomi yang terselenggara dengan melakukan produksi untuk kebutuhan sendiri, sedangkan ekonomi pasar terjadi sebagai akibat terciptanya hubungan antara dua pihak karena adanya penawaran (supply) dan permintaan (demand) sehingga terjadilah kebutuhan dan transaksi (Wibisono, 1991: 23). Proses tersebut dapat ditelusuri melalui bukti-bukti arkeologi.

Sumber-sumber sejarah dan etnografi menggambarkan buktibukti arkeologi mengenai mekanisme pelayaran dan perdagangan di laut Jawa, sudah dimulai sekitar awal abad ke-3 SM. Waktu itu Indonesia (Nusantara) telah mengadakan hubungan dengan Asia Tenggara. Ditemukannya artefak perunggu di situs Pasir Angin juga memberikan gambaran bahwa benda-benda tersebut bukan produksi lokal melainkan telah dibawa dari tempat asalnya ke wilayah situs. Dalam hal ini apakah sebagai cinderamata (persembahan) oleh pendatang asing atau merupakan komoditi yang diperdagangkan (barter) dengan barang yang dihasilkan oleh masyarakat lokal. Untuk membahas permasalahan tersebut diperlukan suatu pendekatan. Dalam hal ini pendekatan yang digunakan adalah pendekatan ekonomi yang pernah berlangsung pada masa prasejarah di situs Pasir Angin.

Mengacu kepada Soni Wibisono (1991: 21-32), bahwa tindakan ekonomi bersumber pada problem untuk memenuhi kebutuhan dasar dan problem meraih kepuasan atas keinginan. Apabila pengertian tersebut dijabarkan, akan diperoleh jenis kebutuhan, yaitu untuk memuaskan dorongan biologis yang bersifat material (makan, tempat tinggal), dan kebutuhan yang bersifat psikologis (keagamaan, pengakuan), serta kebutuhan untuk mendapatkan keuntungan. Dalam hal ini lingkungan menjadi fisik yang dipandang sebagai sumber pertama untuk memenuhi kebutuhan material (makan, sandang, papan, dan peralatan). Kecenderungan ini menyebabkan lingkungan akan dipandang sebagai suatu yang terbatas meskipun menyediakan segalanya, dan sampai pada suatu saat tidak dapat memenuhi keinginannya. Manakala terjadi ketaktersediaan barang yang 
diinginkan, maka manusia akan berbuat sesuatu yang ekonomis. Di sini akan terlihat bahwa proses ekonomi diikuti dengan aktivitas manusia, sehingga dapat diartikan cara manusia sebagai individu dalam memecahkan masalah ada batasnya, dan apabila untuk mendapatkan barang tidak terpenuhi di lingkungannya, manusia memerlukan pasokan dari manusia lain baik berasal dari dalam maupun luar kelompoknya. Dalam kaitannya dengan pernyataan tersebut kemudian muncul bentuk perekonomian yang saling bergantung satu sama lain. Problem kelangkaan dalam pemenuhan kebutuhan atau keinginan ini menempatkan manusia untuk melakukan tugas-tugas dan kegiatan pokok, yaitu memproduksi barang dan jasa, dan mengatur pendistribusiannya. Melalui caracara tersebutlah manusia memenuhi kebutuhannya. Dengan kata lain ekonomi berhubungan erat dengan aspek-aspek kehidupan manusia memproduksi barang dan jasa, serta pendistribusiannya (Heilbroner, 1982: 16-19).

\section{PEMBAHASAN}

Timbul Haryono (1994: 175) seperti dikutip oleh Sudarti (1999:138), bahwa perdagangan logam timah, perak, dan tembaga telah menjadi salah satu aspek penting dalam kegiatan perekonomian sejak jaman perunggu di Asia Barat Daya setidak-tidaknya sejak millennium ke-3 dan ke-2 SM. Para ahli menduga bahwa timah yang digunakan di wilayah tersebut di datangkan dari daerah Asia Tenggara, dan sampai di situs bagaimana pendistribusiannya. $\mathrm{Di}$ perairan Nusantara melengkapi pelayaran dan perdagangan di Asia yang dibuktikan dengan ditemukan adanya kapal-kapal dagang yang tenggelam dengan barang komoditi sebagai muatannya seperti keramik asal Cina, Thailand, dan Vietnam, serta logam yang diidentifikasi sebagai benda berbahan emas, perunggu, besi, tembaga, dan timah (Widiati, 2007: 21).

Sementara

Santoso Soegondo (1991: 33-42) dalam Analisis Hasil Penelitian Arkeologi II, jilid 1, bahwa kehidupan ekonomi masyarakat prasejarah bersangkut paut dengan segala keperluan atau kehidupan sehari-hari, serta tergantung pada keadaan lingkungan, teknologi, dan sistem bertempat tinggal. Oleh karena itu uraian tentang kehidupan ekonomi masyarakat prasejarah meliputi a) kehidupan ekonomi masyarakat yang masih berada dalam taraf kehidupan berburu dan mengumpulkan makan; b) kehidupan ekonomi masyarakat yang telah mengenal cara-cara bercocok tanam; c) kehidupan ekonomi masyarakat yang berada dalam taraf kemajuan teknologi. Berkaitan dengan pokok bahasan dalam tulisan ini maka hanya butir $\mathrm{c}$ ) yang akan digunakan untuk menguraikan mengenai hubungan antara artefak perunggu dan perekonomian masyarakat Pasir Angin pada masa prasejarah.

Sebagian besar artefak logam ditemukan pada waktu kegiatan ekskavasi di situs dengan karakteristik penguburan atau pemujaan, sehingga memberikan gambaran bahwa pada masa itu perunggu mempunyai peranan yang penting dalam kehidupan sosial masyarakatsebagai sarana untuk memenuhi kebutuhan hidup pada masa itu. Sementara lain nekara 
diketemukan dalam kontek perniagaan.

Pernyataan tersebut dapat dibuktikan dengan ditemukannya sejumlah nekara di wilayah Maluku yakni di kepulauan Gorom dan wilayah Kei Kecil, yang merupakan komoditi niaga atau mungkin sebagai alat tukar (Handoko, 2010: $69)$. Keberadaan nekara di wilayah ini diduga berkaitan dengan perdagangan rempah-rempah. Sejak masa silam Maluku sudah dikenal sebagai penghasil rempah-rempah dan kayu cendana. Komoditi ini menarik bagi pedagang-pedagang asing di antaranya yang datang dari Dong Son. Sementara pendagang dari Dong Son membawa produk budaya mereka, yaitu nekara. Nekara, sebagai barang hasil teknologi tinggi dan dianggap sebagai barang mewah dan tinggi nilainya. Temuan nekara di pulau inimenegaskan bahwa kontak budaya pernah berlangsung sejak masa itu.

Untuk memenuhi kebutuhan hidup alam menyediakan sumberdaya yang dapat dimanfaatkan, tetapi kemudian meluas menjadi kebutuhan sosial, karena manusia tidak pernah puas menikmati hasil produksinya sendiri. Adanya aktivitas tersebut mulailah apa yang disebut produksi kebutuhan barang-barang untuk memenuhi fungsi sosial, sehingga menimbulkan permintaan yang didukung adanya keahlian dan bahan (Prijono, 2013: 137). Apabila cara tersebut tidak terpenuhi, manusia berusaha mendatangkan dari wilayah yang surplus barang tersebut.

Distribusi barang dari tempat produksi ke tempat pemakainya dapat ditelusuri melalui bukti-bukti arkeologi. Berbagai tinggalan budaya bercirikan komoditi ditemukan di Nusantara, baik berasal dari dalam maupun luar Nusantara. Sejak era prasejarah peradaban telah tumbuh di berbagai belahan dunia dan seiring dengan tumbuhnya pusat-pusat peradaban muncul jaringan perdagangan untuk memenuhi kebutuhan terhadap berbagai komoditi (Olson, 2004:140; Handoko, 2010:70). Kehadiran nekara dan bejana perunggu Dongson di wilayah Jawa Barat seperti di Kuningan, Bogor, dan Subang. Sebaran nekara Dongson juga ditemukan di berbagai wilayah Nusantara, ini menegaskan bahwa sejak masa prasejarah terutama pada tingkat perundagian, ribuan tahun lalu telah ada aktivitas niaga dan benda berbahan perunggu merupakan suatu komoditi yang diperdagangkan dan mempunyai nilai ekonomi tinggi pada masa tersebut. Hal ini diperjelas dengan pernyataan Soejono, bahwa hubungan antara Cina khususnya Vietnam dan kawasan Nusantara telah terjadi sejak sebelum abad pertama Masehi (Soejono (1992 : 243).

Untuk menjelaskan hal tersebut di antaranya melalui hasil analisis metalografi terhadap artefak perunggu kapak dan tongkatsitus Pasir Angin, ternyata diketahui sama dengan teknologi yang digunakan untuk membuat nekara tipe Heger I dari Dong Son, yaitu melalui teknik penuangan dan pencetakan. Perbedaan terletak pada komposisi unsur logam penyusun, yaitu perunggu dari Pasir Angin mempunyai kandungan timah (Sn) dan timbal $(\mathrm{Pb})$ yang tinggi. Hal ini disebabkan karena adanya perbedaan fungsi dari benda perunggu tersebut, serta adanya dugaan sebagai produksi daur ulang. Sehingga memerlukan penambahan timah $(\mathrm{Sn})$ sebagai 
pengeras, dan timbel untuk mempermudah proses penuangan.

Bukti lainnya adalah

ditemukannya jejak-jejak pelayaran kuna melalui berbagai bentuk visualisasi perahu baik pada seni lukis yang diterapkan pada dindingdinding cadas di pantai maupun pada dinding-dinding gua Ditemukannya pahatan dan lukisan berbentuk perahu di dinding gua-gua purba di Sulawesi Tenggara dan Selatan, serta Papua menggambarkan perahu sebagai sarana transportasi (Sukendar, 1998/1999: 21-23; Liebner, 2005: 53-58). Ini memberikan gambaran, bahwa perahu memegang peranan penting pada masa itu terutama sebagai sarana transportasi, dan tidak tertutup kemungkinan adanya benda-benda komoditi berupa bahan makanan, hasil pertanian, gerabah, perunggu, dan lain-lain telah dibawa dalam pelayarannnya.

Bukti lain adanya perdagangan antara Indonesia dan Cina juga ditemukan dalam pahatan perahu di sebuah dinding kubur batu dari Dinasti Han abad pertama masehi. Demikian pula pada masa Dinasti Han tampaknya perahuperahu Cina sudah hilir mudik dari Cina ke Indonesia, yang dibuktikan dengan ditemukanya keramik masa Han di Sumatera. Ini membuktikan bahwa pada masa itu sudah ada aktivitas perdagangan antara Cina dan Indonesia (Bellwood, 1985: 272 289). Peluang ini tidak menutup kemungkinan, bahwa perunggu juga merupakan salah satu komoditi yang diperdagangkan.

\section{KESIMPULAN}

\author{
Situs Pasir Angin, sejak \\ masa prasejarah khususnya \\ perundagian ribuan tahun lalu, telah \\ menjadi wilayah setrategis dengan
}

posisi geografisnya melahirkan suatu peradaban awal pemanfaatan teknologi tinggi, di mana hubungan kultural di antara bangsa bertemu.

Melalui perantara pelayaran antar pulau di Nusantara (Indonesia) menumbuhkan subsistem yang menopang tumbuhnya pelabuhanpelabuhan transito sehingga nekara dan benda perunggu lainnya menyebar dan menjadi sumber bahan baku perunggu di beberapa pulau di Nusantara.

Adanya penemuan artefak perunggu di situs Pasir Angin dengan teknik pembuatan yang sama dengan perunggu Dong Son memperkuat bukti bahwa sumber artefak perunggu berasal dari wilayah tersebut. Di samping itu juga merupakan sebagian bukti yang memperkuat dugaan bahwa wilayah Jawa telah masuk dalam struktur Jaringan perdagangan Nusantara dan Internasional.

Catatan: Tulisan ini merupakan pengembangan dengan perbaikan judul dan sebagian isi makalah yang disampaikan pada Seminar Forum Peneliti Kementerian Pendidikan dan Kebudayaan di Balikpapan tahun 2013, dan belum diterbitkan. 


\section{DAFTAR PUSTAKA}

Anggraeni, Nies dan Rokhus Due Awe, 1988. "Unsur Budaya Pasir Angin" dalam Rapat Evaluasi Hasil Penelitian Arkeologi III. Jakarta: Departemen Pendidikan dan Kebudayaan. HIm. 339-355

Aziz, Fadhilla Arifin dan Sudarti. 1997/1998. "Komoditi Pertukaran Bahan Baku ada Awal Masehi di Bali" dalam Pertemuan IImiah Arkeologi VII. Jilid I. Jakarta: Proyek Penelitian Arkeologi. HIm. 154-169.

Bassett, Jet all, 1979. Vogel's Textbook of Quantitative Inorganic Analysis Beccles and London - Willian Clowea \& Sons Limited.

Bellwood, Peter. 1985. Prehistory of The Indo-Malaysian Archipelago - Australia: Academic Press.

Bintarti, D. D. 1987.Bronze Kattledrums in Burial Contex in Indonesia, XVII Pasific Science Congress, Seoul, Korea.

Fagan, Brian. 1991. In The Begining, An Introduction - New York - R. R. Dennelley \& Sons Company.

Handoko, Wuri. 2010. "Jejak Perdagangan Internasional Maluku Masa lampau Dalam Perspektif Ekonomi dan Politik". Proceeding. Perdagangan, Pertukaran dan Alat Tukar Di Nusantara dalam Lintasan Masa.Bandung, 22-24 Juni 2010.Kementerian Kebudayaan dan Pariwisata. HIm. 69-78.

Haryono, Timbul. 1994. Aspek Teknis dan Simbolis Artefak Perunggu Jawa Kuno abad XII-X. Disertasi, untuk Memperoleh Derajat Doktor dalam IImu Sastra pada Universitas Gadjah Mada, Yogyakarta.

Hodges, Henry. 1968. Artifact. An Introduction to Early Materials and Tecnology. Third Impression. Pall Mall London: John Bakar Publishers.

Heekeren, H. R. Van.1958. The Bronze-Iron Age of Indonesia, S. CravenhageMartinus, Nijhoff.

Heilbroner, Robert. L. 1982. Terbentuknya Masyarakat Ekonomi. terjemahan Sutan Dianjung. Jakarta: Ghalia Indonesia.

Kempers, Bernet. A. J. 1988. The Kattledrum of Southeast Asia. G. J. Barstra (editor). AA Balkena/Rotherdam/Bookfield: Modern Quarternary.

Liebner, Horst H. 2005. "Perahu-Perahu Tradisional Nusantara Suatu Tinjauan Sejarah perkapalan dan Pelayaran". Eksplorasi Sumberdaya Budaya Maritim. Jakarta: Departemen Kelautan dan Perikanan Republik Indonesia bekerja sana dengan Universitas Indonesia.

Olson. Steve. 2004. Mapping Human History: gen, Ras dan Asal-Usul Manusia . Jakarta: PT Serambi Ilmu Semesta.

Prijono, Sudarti. 2006. Pemaanfaatan Analisis Metalografi Dalam Identifikasi Perunggu Masa perundagian.Dalam Forum Arkeologi No.II/Oktober 2006. Hal 39-54

Prijono, Sudarti. 2013. "Sumberdaya Alam Situs Keramat Teluk, Kecamatan Blambangan Pagar Kaitannya Dengan Aspek Perdagangan". Prosiding 
Seminar Nasional Dalam Rangka 100 Tahun Purbakala. Bandung 26-28 Agustus 2013. Jatinangor: Alqaprint. HIm. 135-146.

Smith, Cyril Stanley. 1973. Bronze Tecnology in the East: Amettalurgical Study of Early Thai Bronzes with Some Specullations on the Cultural Transformation of Tecnology. In M. Teich and R. Young (ed). Changed Perspectives, in the History of Science. Essay in Honor of Joseph Needam.

Soegondo, Santoso dan Budi Santoso Aziz. 1988. "Pasir Angin dan Hubungannya Dengan Situs Prasejarah di Jawa Barat". Rapat Evaluasi Hasil Penelitian Arkeologi III. Jakarta: Departemen Pendidikan dan Kebudayaan. HIm. 305-325

Soegondo, Santoso. 1991. "Kehidupan Ekonomi Masyarakat Prasejarah di Indonesia". dalam Analisis Hasil Penelitian Arkeologi II. Jakarta: Departemen Pendidikan dan Kebudayaan, HIm : 33-42.

Soejono. R.P (ed). 1992. Sejarah Nasional Indonesia, jilid I, Jakarta: Balai Pustaka

Sudarti. 1999. Teknik Pembuatan Artefak Perunggu Prasejarah Masa Perundagian di Jawa dan Bali. Tesis S2. Program Pascasarjana. Jakarta: Universitas Indonesia

Sukendar, Haris.1998/1999. Pustaka Wisata Budaya Perahu Tradsional Nusantara. Jakarta: Proyek Pengembangan Media Kebudayaan, Direktorat Jenderal Kebudayaan, Departemen Pendidikan dan Kebudayaan.

Supiyem, Ir (ketua). 1985. Kajian Tembaga, Bandung, Pusat Pengembangan Teknologi Mineral, Direktorat Jenderal Petambangan Umum, Departemen Pertambangan dan Energi.

Surdia, Tata dan Kenji Chiijiwa.1986. Teknik Pengecoran Logam, Cetakan Kelima. Jakarta: Pt. Pradnya Paramita

Wibisono, Soni. Crh, 1991. "Subyek dan Obyek Studi Arkeologi Ekonomi". Proceedings Analisis Hasil Penelitian Arkeologi II. Jilid 1. Jakarta, Departemen Pendidikan dan Kebudayaan. HIm. 21-32

Widiati, 2007. Ragam Temuan Dari Situs Kapal Tenggelam Perairan Cirebon, Jawa Tengah.Dalam Varuna Jurnal Arkeologi Bawah Air. Vol. 1/2007. HIm. 16-25 